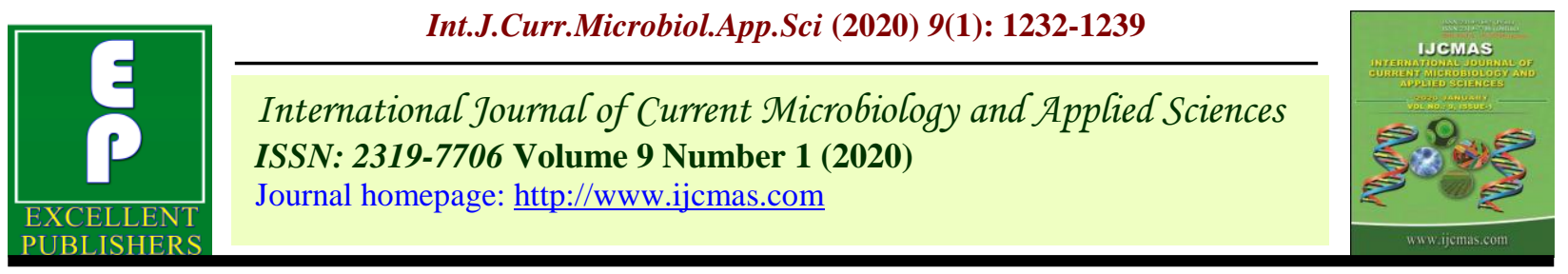

Original Research Article

https://doi.org/10.20546/ijcmas.2020.901.136

\title{
Genetic Characterization of Desi Cotton Hybrids Using Molecular Markers
}

\author{
Khushbu Patel ${ }^{1}$, B. K. Rajkumar ${ }^{2 *}$, Preeti R. Parmar $^{2}$, D. H. Patel $^{2}$ and B. G. Solanki ${ }^{2}$ \\ ${ }^{1}$ Shree Ramkrishna College of Computer Education and Applied Sciences, Surat \\ ${ }^{2}$ Main Cotton Research Station, Navsari Agricultural University, Athwa Farm, Surat, India \\ *Corresponding author
}

\section{A B S T R A C T}

The desi cotton hybrids viz., G.Cot.DH-7 (Sujay x G 27) and G.Cot.DH-9 (4011 x 824) and their parents were characterized using morphological and molecular markers. The desi cotton hybrids and their parents showed variations for

\section{Keywords}

RAPD, ISSR, SSR, Molecular marker, Desi hybrid, Cotton

Article Info

Accepted:

15 December 2019

Available Online:

20 January 2020 morphological characters viz., foliage, leaf shape, leaf hairiness, growth habit, pollen colour, bolls shape and stem hairiness. Based on the distinct morphological characters one can identify true hybrid. A set of 25 RAPD and 19 ISSR were used for molecular characterization of desi hybrids. Primer ISSR9 amplified two polymorphic loci designated as ISSR9_200bp (Sujay) and ISSR9_550bp (G.27) in G.Cot.DH-7; this heteroallelic marker not only differentiated the parents but also confirmed true hybrid. RPI7 amplified a polymorphic marker of approximately $450 \mathrm{bp}$ and $500 \mathrm{bp}$ in the female parent (4011) and hybrid G.Cot.DH-9 but not in the male parent (824). Similarly, RPI8 primer amplified allele of 550bp in the male parent and the hybrid G.Cot.DH-9, but not in its female parent. Thus, the combination of RPI7_450 (4011) and RPI8_550 (824) marker can be used for identification of G.Cot.DH-9. Our study revealed the parentage and desi hybrid confirmation using molecular marker and the markers identified would be valuable genomic tool for desi cotton breeding programs.

\section{Introduction}

Cotton is one of the most important commercial crops popularly known as the "White Gold". The existence of cotton thread in India is traced back to the Rigveda about 4000 B.C. and India is not only the birth place of cotton but also only country to grow all four species of cultivated cotton on commercial scale, two tetraploid called new world cotton (Gossypium hirsutum and
Gossypium barbadense) and two diploid called old world cotton or desi cotton (Gossypium herbaceum and Gossypium arboreum). India also has a pride place in the global cotton scenario due to several distinct features such as the largest cotton growing area, cultivation of all the four cultivated species, large area under tetraploid cotton, one of the largest producers of long and extralong staple cotton, native home of old world cultivated cotton and wide diversity in agro- 
climatic conditions under which cotton is grown. During the pre-independence era, about 97 per cent of cotton area was under Asiatic (desi) cottons and only 3 per cent area was under American cotton (G. hirsutum). Asiatic (desi) cottons are known for their good agronomic base, strong resistance to disease and pest, abiotic stress tolerance (salinity and drought) and suitability under rainfed conditions (Patel and Chaudhari, 2015). After the introduction of $B t$ cotton, area under cultivation of desi cotton decreased significantly but now there is a big demand of short staple cotton for denim and surgical cotton, and hence price of short staple cotton is increased due to shortage of desi cotton (Patel and Chaudhari, 2015).

The varieties and hybrids attain acceptance when the farmer gets genetically pure seeds of high standards. For this purpose, each cultivar should be properly defined with suitable descriptors, so as to maintain its identify during seed production through field inspection and certification. Apart from this, characterization of cultivars is also required for their protection under PPV \& FR Act 2001. In India, while certain diagnostic features for released and notified crop varieties and hybrids are known and used in seed certification, but by and large descriptors are incomplete. Traditionally, it has been the practice to carry out Grow Out Test (GOT) to analyze the genetic purity of hybrid seeds using morphological traits (Ankaiah et al., 2005; Tatineti et al., 1996;). However, morphological differences between true hybrids and off types are not always apparent and cannot be recognized easily, especially when the parents are genetically similar. The sensitivity of morphological traits to the environment further limits the application of GOT. With the advent of the molecular marker technology, it is now possible to test the purity of the hybrid seed immediately after harvesting and processing by DNA markers. DNA markers such as RFLP (Pendse et al., 2001; Dongre and Parkhi, 2005) RAPD (Venu, 2001; Rao et al., 2002; Mehetre et al., 2007), AFLP (Rana and Bhat, 2004), SSR (Rana, 2003; Dongre and Parkhi, 2005; Saravanan et al., 2007) and ISSR (Dongre and Parkhi, 2005; Rana et al., 2006) have been used to rapidly screen genetic purity of hybrids. The objective of the present study was to test genetic purity and identify the markers for desi cotton F1 hybrids G.Cot.DH7 and G.Cot.DH-9 and its parents using RAPD and ISSR markers.

\section{Materials and Methods}

The material for the present investigation comprised of intraspecific cotton $\mathrm{F}_{1}$ hybrids viz., G. Cot.DH-7 its parents Sujay (female) and G-27 (male); and G. Cot. DH-9 and its parents 4011 (female) and 824 (male) were obtained from Main Cotton Research Station (MCRS), Navsari Agricultural University (NAU), Athwa Farm, Surat.

Grow out test (GOT) has been employed to assess the purity of hybrid seeds using morphological traits. The traits such as foliage, leaf shape, lobs, leaf hairiness, growth habit, pollen colour, bolls shape, stem hairiness, and other DUS testing character were studied to distinguish the hybrids from off types.

\section{DNA isolation}

Four to five fresh, young, healthy leaves were collected from the hybrids G.Cot.DH-7 and G.Cot.DH-9 along with their parents and kept at $4^{\circ} \mathrm{C}$ in the sterilized cooling box to avoid drying and minimize the phenolics compound level and brought to laboratory for DNA isolation. Genomic DNA isolated from young fully expanded leaves of hybrids and their respective parents using the CTAB method with minor modification (Saghai-Maroof et 
al., 1984). Quality and quantity of DNA were estimated by measuring O.D. at $260 / 280 \mathrm{~nm}$ in UV Spectrophotometer. Intactness of genomic DNA was checked on agarose gel $(0.8 \%)$.

\section{RAPD and ISSR amplification}

The genomic DNA is subjected to PCR. A total of 25 RAPD and (GeNei primers: RPI1 to RPI25) and 19 ISSR (ISSR 1 to ISSR 15) primers were used for hybrid analysis. RAPD and ISSR each of $25 \mu \mathrm{l}$ reaction volume were carried out in $200 \mu 1 \mathrm{PCR}$ tube. Each reaction mixture $(25 \mu \mathrm{l})$ for PCR amplification consisted of $10 \mathrm{X}$ reaction buffer $(10 \mathrm{mM}$ Tris- $\mathrm{HCl}, \mathrm{pH} 8.3$ and $50 \mathrm{mM} \mathrm{KCl}$ ), $2.5 \mathrm{mM}$ $\mathrm{MgCl}_{2}, 3 \mathrm{U}$ Taq DNA polymerase; $2.5 \mathrm{mM}$ each dATP, dTTP, dCTP and dGTP (all reagents from Fermentas), 10 pico mole primer (Bangalore GeNei India), and $10 \mathrm{ng}$ genomic DNA template.

The DNA amplification was carried out in thermocycler. For RAPD analysis, an initial denaturing step of $6 \mathrm{~min}$ at $94^{\circ} \mathrm{C}$ was followed by $35 \mathrm{PCR}$ cycles (denaturing at $94^{\circ}$ $\mathrm{C}$ for $45 \mathrm{sec}$, primer annealing at $36^{\circ} \mathrm{C}$ for 1 min and primer extention at $72^{\circ} \mathrm{C}$ for $2 \mathrm{~min}$ ). For ISSR analysis, an initial denaturing step of $10 \mathrm{~min}$ at $94^{\circ} \mathrm{C}$ was followed by 35 PCR cycles (denaturing at $94^{\circ} \mathrm{C}$ for $1 \mathrm{~min}$, primer annealing at $49^{\circ} \mathrm{C}$ for $1 \mathrm{~min}$ and primer extension at $72^{\circ} \mathrm{C}$ for $2 \mathrm{~min}$ ). A final step of $10 \mathrm{~min}$ at $72^{\circ} \mathrm{C}$ was carried out for polishing the ends of PCR products in all RAPD and ISSR markers.

\section{Resolution of PCR products}

Amplified DNA fragments were separated on $1.5 \%$ agarose gels and stained with ethidium bromide. Running buffer containing TBE [Tris-buffer, boric acid and EDTA ( $\mathrm{pH}$ 8.0)] was used for electrophoresis. Wells were loaded with $15 \mu \mathrm{l}$ of amplified sample and $3 \mu \mathrm{l}$ of loading buffer (sucrose, bromophenol blue and Xylene cyanol). The gel was run at $80 \mathrm{~V}$ (constant) to separate the amplified bands. The standard DNA marker (100 bp) was also run along with the samples. The separated bands were documented under UV transilluminator and photographed by Gel documentation system (Alpha Innotech. U.S.A.) and analyzed.

\section{Results and Discussion}

\section{Morphological characterization}

The hybrid G.Cot.DH-7, G.27, and 4011 exhibited erect type of growth habit, while G.Cot.DH-9, Sujay, and 824 had semi-erect type of growth (Table 1). The variation exhibited by the genotypes for growth habit is due to genetic character of the genotypes. The genotypes exhibited variation for stem hairiness and grouped as sparsely hairy (G.Cot.DH-7, G.Cot.DH-9, 4011, and 824) and glabrous (Sujay). Similarly, Sethi et al., (1960) reported that stem hairiness is a genetically controlled and it varies from genotype to genotype. However, the five lobs per leaves were observed in both hybrids and their parents. The leaf foliage colour of G.Cot.DH-7 and Sujay was light green and G.27 was dark green. Whereas in case of hybrid G.Cot.DH-9 and female parent 4011 leaf were green and male parent (824) was dark green in colour. The genotypic variation in the colour of the leaf may be due to genetic character of the parents and may be also due to edaphic and environmental conditions such as nutritional factors and light intensity during crop growth.

All the genotypes except 824 have medium hairs on leaves. However, the earlier study revealed that hair on leaf behaves like a simple mendelian trait giving 1:2:1 ratio in crosses between sparsely hairy and medium hairy leaves (Harland, 1944). The petal colour of the flower is one of the important 
characters for characterization, based petal color the genotypes were categorized as cream (G.27), yellow (G.Cot.DH-9, G.Cot.DH-7, Sujay and 824) and deep yellow (4011). Similarly, petal spot is used as marker for varietal identification, which is present in G.Cot.DH-9, G.Cot.DH-7, Sujay and 824 and absent in 4011 parent. The variation in petal spot is due to genetic constituent of the genotypes which has cumulative effect and is governed by dominant gene as it was reported by Ahuja et al., (2006) in cotton. The variation in the anther colour was noticed and the genotypes were grouped as dark yellow in both the female parent (Sujay and 4011) as well as hybrids (G.Cot.DH-7 and G.Cot.DH9) and light yellow in male parents G.27 and 824 , which is a heritable character and it is genetically controlled. The cylindrical boll shape observed both the hybrid and their parent except 824 (elongated) and it is genetically controlled by the genotype.

\section{Molecular characterization}

The assessment of genetic purity of hybrid using GOT has limitations, warrants faster, reliable and precise assessment of genetic make up of a genotype through molecular markers. Thus, in the present study aimed at confirmation of cotton F1 desi hybrids viz., G.Cot.DH-7 (Sujay × G.27) and G.Cot.DH-9 $(4011 \times 824)$ using 25 RAPD and 19 ISSR primers.

\section{Identification the hybrid G.Cot.DH-9}

Out of 25 RAPD, two decamer random primers RPI-7 and RPI-8 were found extremely polymorphic between male and female parents respectively. These highly informative primers not only differentiated 4011 and 824 but also confirmed the parentage of their G.Cot.DH-9 hybrid. The two random primers amplified collectively six fragments, while the number of resolvable loci was two and one for the primers RPI7and RPI-8, respectively. RPI-7 generated a polymorphic marker of approximately $450 \mathrm{bp}$ and 500bp in the female parent (4011) and in hybrid but not in the male parent. However, the RPI-8 primer amplified a different allele of size $550 \mathrm{bp}$ in the male parent (824). The same allele size of 550bp was expressed in the hybrid, but not in its female parent. The presence of both female and male parent alleles indicated the result of crossing between two parents (hybrid). The observed banding pattern was highly specific to this hybrid (Figure 1). Polymorphic molecular markers produced unique banding and not only discriminated the two cotton parents, but also identified their true hybrids. Polymorphism revealed by RAPDs is based on the position and orientation of primers annealing site and the interval they span. Polymorphism between individuals can arise through nucleotide substitutions and insertions or deletions (Williams et al., 1990). This technique can be adopted for large scale screening of hybrids in cotton (Dongre and Parkhi 2005).

\section{Identification the hybrid G.Cot.DH-7}

Among 25 RAPD primers, RPI-7 identified two female specific allele amplicons about 450bp and 500bp for hybrid G.Cot.DH-7. Further, out of 19 ISSR primers, two primers ISSR-9 and ISSR-12 showed polymorphism in parents. Out of which only one primer ISSR-9 was found to be heteroallelic for parents. ISSR-9 produced two distinguishable amplicons, amplicons about 200bp was specific to female (Sujay) and another amplicons about 550bp was specific to male parent (G.27) (Figure 2). Whereas, ISSR-12 primer resulted in amplification of $700 \mathrm{bp}$ male specific amplicon that was present in hybrid G.Cot.DH-7. 
Table.1 Morphological characters of cotton hybrid and its parents

\begin{tabular}{|l|l|l|l|l|l|l|l|}
\hline $\begin{array}{l}\text { Sr. } \\
\text { No. }\end{array}$ & Character & $\begin{array}{l}\text { Female } \\
\text { (Sujay })\end{array}$ & $\begin{array}{l}\text { Male } \\
(\mathbf{G . 2 7})\end{array}$ & $\begin{array}{l}\text { G.Cot.DH- } \\
\mathbf{7}\end{array}$ & $\begin{array}{l}\text { Female } \\
\mathbf{( 4 0 1 1}\end{array}$ & $\begin{array}{l}\text { Male } \\
\mathbf{( 8 2 4 )}\end{array}$ & $\begin{array}{l}\text { G.Cot.DH- } \\
\mathbf{9}\end{array}$ \\
\hline $\mathbf{1}$ & Foliage & Light Green & $\begin{array}{l}\text { Dark } \\
\text { Green }\end{array}$ & Light green & Green & $\begin{array}{l}\text { Dark } \\
\text { Green }\end{array}$ & Green \\
\hline $\mathbf{2}$ & Leaf shape & Semidigitate & Palmate & Semidigitate & Palmate & Palmate & Palmate \\
\hline $\mathbf{3}$ & Lobs & 5 lobs & 5 lobs & 5 lobs & 5 lobs & 5 Lobs & 5 Lobs \\
\hline $\mathbf{4}$ & $\begin{array}{l}\text { Leaf } \\
\text { hairiness }\end{array}$ & Medium & Medium & Medium & Medium & Sparse & Medium \\
\hline $\mathbf{5}$ & Habit & Semi-erect & Erect & Erect & Erect & $\begin{array}{l}\text { Semi- } \\
\text { erect }\end{array}$ & Semi-erect \\
\hline $\mathbf{6}$ & Pollen & Dark yellow & $\begin{array}{l}\text { Light } \\
\text { yellow }\end{array}$ & $\begin{array}{l}\text { Dark } \\
\text { Yellow }\end{array}$ & $\begin{array}{l}\text { Dark } \\
\text { yellow }\end{array}$ & $\begin{array}{l}\text { Light } \\
\text { yellow }\end{array}$ & $\begin{array}{l}\text { Dark } \\
\text { yellow }\end{array}$ \\
\hline $\mathbf{7}$ & $\begin{array}{l}\text { Red petal } \\
\text { spot }\end{array}$ & Present & Present & Present & Absent & Present & Present \\
\hline $\mathbf{8}$ & $\begin{array}{l}\text { Petal } \\
\text { colour }\end{array}$ & Yellow & Cream & Yellow & $\begin{array}{l}\text { Deep } \\
\text { yellow }\end{array}$ & Yellow & Yellow \\
\hline $\mathbf{9}$ & $\begin{array}{l}\text { Bolls } \\
\text { shape }\end{array}$ & Cylindrical & Cylindrical & Cylindrical & Cylindrical & Elongated & Cylindrical \\
\hline $\mathbf{1 0}$ & $\begin{array}{l}\text { Stem } \\
\text { hairiness }\end{array}$ & Glabrous & $\begin{array}{l}\text { Sparsely } \\
\text { Hairy }\end{array}$ & $\begin{array}{l}\text { Sparsely } \\
\text { Hairy }\end{array}$ & $\begin{array}{l}\text { Sparsely } \\
\text { Hairy }\end{array}$ & $\begin{array}{l}\text { Sparsely } \\
\text { Hairy }\end{array}$ & $\begin{array}{l}\text { Sparsely } \\
\text { Hairy }\end{array}$ \\
\hline
\end{tabular}

Figure.1 Amplification profile of cotton parents and their F1 with polymorphic RAPD primers (RPI-7 and RPI-8) M: marker (DNA ladder), F: female parent one (4011), DH-9: first generation hybrid (G.Cot.DH-9), M: male parent (824)

RPI-7

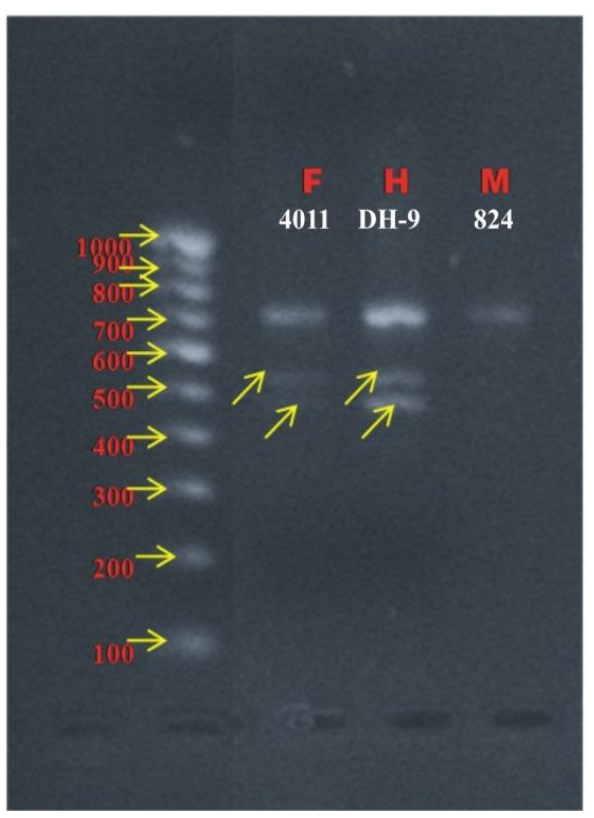

RPI-8

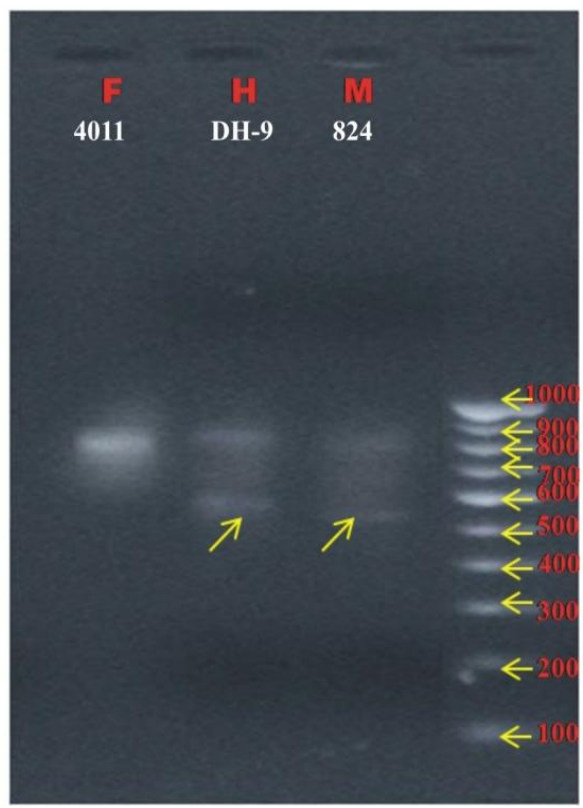


Figure 2 Amplification profile of cotton parents and their F1 with polymorphic ISSR 9. [M: marker (DNA ladder), F: female parent one (Sujay), DH-7: first generation hybrid (G.Cot.DH-7), M: male parent (G.27)]

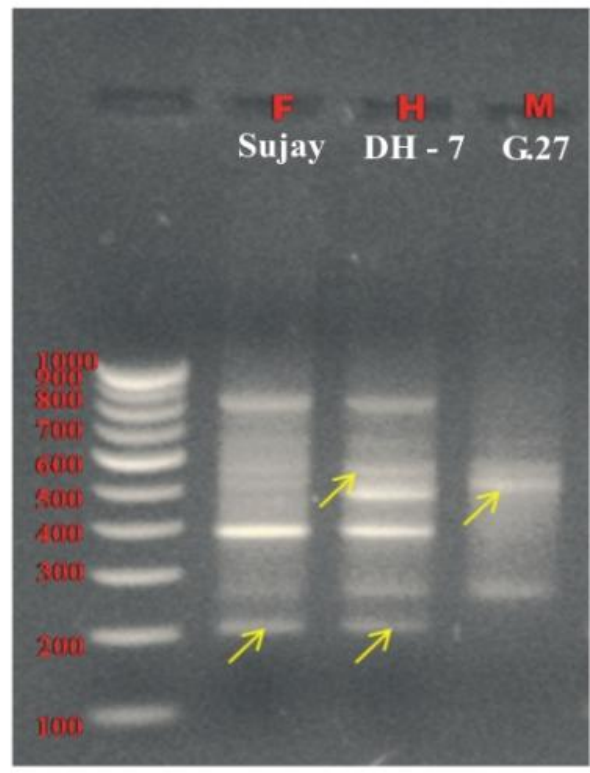

Our results confirm that ISSR markers are efficient tools for the discrimination of $F_{1}$ hybrids from the self-pollinated progeny of female parents in controlled crosses. They can also be effectively used to fingerprint and differentiate plants with highly similar morphological characteristics. The hybridity status of F1 hybrids can be easily verified by comparing amplified polymorphic bands between F1 hybrids and parents (bands specific to the female and male parent). In addition, ISSR markers allow the easy, fast, inexpensive, accurate, reliable, and simultaneous detection of polymorphisms at multiple loci in the genome using low quantities of DNA. These properties have made the markers useful for the genetic analysis of various plants (Reddy et al., 2002). Our results agreed with those of Desai (2014), who reported the use of 19 ISSR primers to identify the parentage of hybrids of cotton. Similarly, Liu et al., (2007) have used 54 ISSR primers to confirm the hybrids of three crosses of the cotton and found that two ISSR primers gave polymorphic DNA bands between male and female parents in each cross and could verify their interspecific hybrids. Eight ISSR primers have also been used successfully in the identification of cotton hybrids (Dongre et al., 2005, 2010 and 2012).

Microsatellite repeats used as primers in ISSR markers, amplify DNA segment present at an amplifiable distance in between two identical microsatellite repeat relatively more stable and repeatable. The polymorphic ISSR markers produced female specific amplicon. Thus ISSRs can be used to identify female parent of the respective hybrid. Though the usefulness and effectiveness of different type of molecular markers were reported, the selection of marker type is of great importance for successful genetic purity testing. In case of dominant markers such as RAPD and ISSR, only those primers which amplify bands specific to the male parent might reveal a proper pattern of a true hybrid as opposed to that of the female parent. 
It can be concluded from this study that it is possible to differentiate the desi cotton hybrids more accurately and efficiently from its parental lines using RAPD and ISSR markers. These molecular markers would be more efficient than GOT as markers are independent of environmental influence. Thus, DNA markers would be more accurate for determining hybrid seed purity.

Conflicts of Interest: The authors declare no competing/conflict or financial interests.

\section{References}

Ankaiah, R., Subba Rao, L.V, Kumar, K.V.S.M., Chaudhary, C.P. and Vidya Sagar, C. (2005). Significance of grow out test in assessing genetic purity of cotton hybrids and their parental lines. Structural Genomics, 1, 53-54.

Ahuja, S. L., Gururajan, K. N. and Dhayal, L. S., 2006, Gene action and morphological characteristics of pink flower and pink filament mutants in cotton (Gossypium hirsutum L.). Journal of Genetics., 85(3): 229-232.

Dongre, A. and Parkhi, V. (2005) Identification of cotton hybrid through the combination of PCR based RAPD, ISSR and microsatellite markers. Journal of Plant Biochemistry and Biotechnology, 14, 53-55.

Dongre, A.B., Raut, M.P., Bhandakar, M.R., Mesharam, K.J. (2011). Identification and genetic purity testing of cotton F1 hybrid using molecular markers. Indian Journal of Biotechnology 10, 301-306.

Dongre, A.B., Raut, M.P., Paired, V.M., Pande, S.S. (2012). Genetic purity testing of cotton F1 hybrid DHH-11 and parents revealed by molecular markers. International Research Journal of Biotech 3, 32-36.

Geng, C.D., Gong, Z.Z., Huang, J.Q. and Dang, Z.L. (1995) Identification of differences between cotton cultivars $(G$. hirsutum) using RAPD method. Jiangsu Journal of Agricultural Science, 11, 2124: 366.

Harland, S. C. 1944, The selection experiments with Peruvian cotton. Soc. Nac. Agraria, Institute of Cotton Genetics Bulletin No. 1. Plant Breeder Abstract, 15: 661.

Liu, Hui, Guijun Yan, Patrick M. Finnegan, and Ralph Sedgley (2007) Development of DNA markers for hybrid identification in Leucadendron (proteaceae). Scientia horticulturae 113, 4: 376-382.

Mehetre, S., Pardeshi, S., Pawar, S., Gahukar, S. and Chavan, U. (2007) In vitro embryo cultured hybrid between Gossypium hirsutum and Gossypium arboreum: hybridity confirmation. Journal of Cotton Research and Development, 21: 131-139.

Patel, N. N., and Pinal Chaudhari (2015) Combining ability study for yield and its component raits through linex tester mating design in Asiatic (Gossypium herbaceum L.) cotton." Journal of Cotton Research and Development, 29, 1: 19-22.

Pendse, R., Malhotra, S., Pawar, S. and Krishna, T. (2001) Use of DNA markers for identifying inbreds and hybrid seeds in cotton (Gossypium hirsutum L.). Seed Science and Technology, 29: 503-508.

Rana, M. and Bhat, K. (2004) A comparison of AFLP and RAPD markers for genetic diversity and cultivar identification in cotton. Journal of Plant Biochemistry and Biotechnology, 13: 19-24.

Rana, M.K. (2003). Use of DNA markers for assessing purity of parental lines and hybrids in various crops. IARI, New Delhi.

Rana. M.K., Singh, S. and Bhat, K.V. (2006). RAPD, STMS and ISSR markers for genetic diversity and hybrid seed purity 
testing in cotton. Seed Science and Technology, 35: 709-721.

Rao, R.G.S., Dadlani, M. and Mahapatra, T. (2002). F1 hybrid seed analysis by RAPD markers in cotton hybrid (Gossypium spp). Seed Technology News, 32: 162.

Reddy, M. Pradeep, N. Sarla, and E. A. Siddiq. (2002) "Inter simple sequence repeat (ISSR) polymorphism and its application in plant breeding." Euphytica 128 (1): 9-17.

Saghai-Maroof MA, Soliman K M, Jorgensen RA and Allard RW. (1984). Ribosomal DNA spacer length polymorphism in barley; Mendelian Inheritance, chromosomal location and population dynamics. USA, 8014-8018.

Sethi, B. L., Sikka, S. M., Dastor, R. H., Gadkari, P. D., Balasubrahmanyan, R., Maheshwari, P., Rangawamy, N. S. and Joshi, A. B., 1960, Cotton in India: A monograph, Vol. I, Indian Central Cotton Committee, Mumbai.

Tatineti, V., Cantrell, R.G. and Davis, D.D. (1996). Genetic diversity in elite cotton germplasm determined by morphological characteristics and RAPDs. Crop Science, 36, 186-192.

Venu, A. (2001). Development of molecular marker based seed identification procedure for cotton parents and hybrids (Gossypium spp.). M. Sc. Thesis, Tamil Nadu Agricultural University, Coimbatore, India.

Williams, John GK, Anne R. Kubelik, Kenneth J. Livak, J. AntoniRafalski, and Scott V. Tingey (1990) DNA polymorphisms amplified by arbitrary primers are useful as genetic markers." Nucleic Acids Research 18, 22: 65316535.

\section{How to cite this article:}

Khushbu Patel, B. K. Rajkumar, Preeti R. Parmar, D. H. Patel and Solanki, B. G. 2020. Genetic Characterization of Desi Cotton Hybrids Using Molecular Markers. Int.J.Curr.Microbiol.App.Sci. 9(01): 1232-1239. doi: https://doi.org/10.20546/ijcmas.2020.901.136 